\title{
Growth and reproduction of the gilthead seabream Sparus aurata in Mellah lagoon (north-eastern Algeria)
}

\author{
LAMYA CHAOUI $^{1}$, MOHAMED HICHEM KARA ${ }^{1}$, ERIC FAURE ${ }^{2}$ \\ and JEAN PIERRE QUIGNARD ${ }^{3}$ \\ ${ }^{1}$ Laboratoire Bioressources Marines, Université d'Annaba, BP 230 Oued Kouba, Annaba 23003, Algérie. \\ E-mail: chaouilamya@hotmail.com \\ ${ }^{2}$ Laboratoire de systématique évolutive, Université de Provence, Case 5, place Victor Hugo, \\ 13331 Marseille cedex 3, France. \\ ${ }^{3}$ Laboratoire d'Ichtyologie méditerranéenne, 1, allée de l'ermitage, 34170 Castelnau-Le-Lez, France.
}

\begin{abstract}
SUMMARY: Gilthead seabream Sparus aurata (L.), a protandrous hermaphrodite, was caught in Mellah lagoon (Algeria) from July 1997 to June 1998. Its age, growth and reproduction were studied. Fish ranged in size from 157 to $610 \mathrm{~mm}$ total length and weighed from 60 to $4000 \mathrm{~g}$ wet weight. There were fish aged $1^{+}$to $7^{+}$years old in the samples. Direct scale readings were made by counting the number of rings. These were compared with the data obtained by backcalculating the lengths at different ages. These two methods were in agreement and showed that the growth rate of gilthead seabream in Mellah lagoon is very high compared to other study areas. The growth parameters of the Von Bertalanffy equation were: $\mathrm{L}_{\infty}=55.33$ $\mathrm{cm}, \mathrm{K}=0.513$, to $=-0.282$, with $\Phi^{\prime}=7.359$. The fitted length-weight relationship was $\mathrm{W}=1.292 .10^{-2} \mathrm{~L}^{3.06}$. The reproductive season extended from October to January, with a peak in December. Sex inversion occurred at a total length of 44 $\mathrm{cm}$. Sexual maturity was reached at $32.6 \mathrm{~cm}$ total length.
\end{abstract}

Keywords: lagoon, gilthead seabream, growth, reproduction.

RESUMEN: CRecimiento y Reproducción de la dorada, Sparus aURata en la laguna de Mellah (nordeste de ARGELIA). - Se capturaron ejemplares de dorada, Sparus aurata (L.), una especie hermafrodita proterándrica, en la laguna de Mellah (Argelia) entre Julio de 1997 y Junio de 1998. Se estudiaron la edad, el crecimiento y la reproducción. La talla de los ejemplares estudiados osciló entre 157 y $610 \mathrm{~mm}$ de longitud total, pesando entre 60 y $4000 \mathrm{~g}$ (peso fresco). Ejemplares de edades comprendidas entre $1^{+}$y $7^{+}$años estuvieron presentes en las muestras. La lectura directa de algunas escamas mediante el conteo del número de anillos fue comparada con los datos obtenidos por retrocálculo de las tallas a distintas edades. Los resultados de los dos métodos fueron similares y mostraron que la tasa de crecimiento de la dorada en la laguna de Mellah es muy alta en comparación con otras áreas de estudio. Los parámetros de crecimiento de la ecuación de Von Bertalanffy fueron los siguientes: $\mathrm{L}_{\mathbf{s}}=55.33 \mathrm{~cm}, \mathrm{~K}=0.513, \mathrm{t}_{0}=-0.282$, con $\mathrm{F}^{\prime}=7.359$. El ajuste de la relación talla - peso fue el siguiente: $\mathrm{W}=1.292 .10^{-2} \mathrm{~L}^{3.06}$. La estación reproductiva estuvo comprendida entre Octubre y Enero, con un pico en Diciembre. La inversión de sexo tuvo lugar a una longitud total de $44 \mathrm{~cm}$. La madurez sexual se alcanzó a una longitud total de $32.6 \mathrm{~cm}$.

Palabras clave: laguna, dorada, crecimiento, reproducción.

\section{INTRODUCTION}

The euryhaline and eurytherm gilthead seabream Sparus aurata (L., 1758) is an inshore species that frequents Posidonia oceanica beds and rocky and sandy areas. Adult individuals may migrate into lagoons or estuaries. Gilthead seabream is common in the Mediterranean Sea, but very rare in the Black Sea (Bânârescu, 1964). It is also present in the eastern part of the Atlantic Ocean, from Britain to Cape Verde and the Canaries (Bauchot and Hureau, 1986). 
With a yearly production of about 101,598 $\mathrm{t}$ in 2002 (Anonyme, 2004) in Europe and the Mediterranean Sea, cultivation of gilthead seabream has benefited from considerable research effort (Chatain, 1997; Shields, 2001). However, research on its biology in its natural environment is out-ofdate and limited (Lasserre and Labourg, 1974; Lasserre, 1976; Arnal et al., 1976; Suau and López, 1976; Chauvet, 1979; Ferrari and Chieregato, 1981; Wassef and Eisawy, 1985; Rosecchi, 1987), notably with regard to reproduction (Arias, 1980). Recently, Kraljevic and Dulčić (1997) studied its growth in the Mirna estuary in the north of the Adriatic Sea, whereas Pita et al. (2002) studied its dietary pattern within the lagunar system of Ria Formosa in south Portugal. Sex inversion in wild populations is treated from an ultrastructural point of view by BrusléSicard and Fourcault (1997).

In Mellah lagoon, the sparidae family is represented by seven species, with gilthead seabream occupying an important place with a production of $12 \mathrm{t}$ in 1999, that is, $98 \%$ of sparid fishes. However, the biology of gilthead seabream in this particular environment has never been studied in this lagoon. The lagoon is characterised by the presence of a bordigue (fixed fishing gear) which transforms it into a big basin for extensive aquaculture based on trapping the fish. Thus, this work presents new data on the growth and reproduction of gilthead seabream in the area of extensive lagoon aquaculture.

\section{MATERIAL AND METHODS}

Situated in the extreme east of Algeria $\left(8^{\circ} 20^{\prime} \mathrm{E}\right.$, $\left.36^{\circ} 54^{\prime} \mathrm{N}\right)$, "Mellah" is a lagoon of 865 ha, with an average depth of $3.5 \mathrm{~m}$. A total of 632 gilthead seabream were taken by professional fishermen from July 1997 to June 1998. Some of the fish $(65 \%)$ were fished with monofilament gillnets that were $3 \mathrm{~m}$ high with a stretched mesh size of $3.5 \mathrm{~cm}$. The rest (35\%) came from the bordigue, particularly at the time of their migration towards the sea (from October to December).

The fish total length was measured, and their age was determined by scale-reading. Five to seven scales were removed from under the left pectoral fin, cleaned and observed at a low magnification ( $\mathrm{x}$ 32 ). With the help of an ocular micrometer, the total scale radius $(\mathrm{R})$ and the radii of the different growth rings $\left(\mathrm{R}_{1}, \mathrm{R}_{2}, \ldots, \mathrm{R}_{\mathrm{n}}\right)$ along a median vertical line were measured. In order to determine when these rings formed, we analysed the monthly variations of the scale marginal increment (MI), with $M I=R-R_{n} /$ $R_{n}-R_{n-1}$, where $R_{n}$ and $R_{n-1}$ are respectively the radius of the last and the next-to-last growth rings.

The age-length relationship was backcalculated according to the Lee method (1920). The theoretical size of fishes when the first scales formed was obtained by a regression $\mathrm{L}_{\mathrm{t}}=\mathrm{f}(\mathrm{R})$ based on 100 data pairs $(157 \leq \mathrm{Lt} \leq 579 \mathrm{~mm}, 1.91 \leq \mathrm{R} \leq 8.27 \mathrm{~mm})$. Sizesat-age (age-length key) were compared with the results of the backcalculation. These backcalculations were used to estimate the parameters $\mathrm{L}_{\infty}, \mathrm{K}$ and to of the Von Bertalanffy (1938) growth model, $\mathrm{L}_{\mathrm{t}}=$ $\mathrm{L}_{\infty}\left(1-\mathrm{e}^{-\mathrm{K}(\mathrm{t}-\mathrm{to})}\right)$, by non-linear least squares regression using the Fishparm program (Prager et al., 1989). This software package was also used to fit the overall total length-total weight relationship, $\mathrm{W}=\mathrm{a}$ $\mathrm{L}_{\mathrm{t}}^{\mathrm{b}}$, using data from July 1997 to June $1998(\mathrm{~N}=$ $\left.370,157 \leq \mathrm{L}_{\mathrm{t}} \leq 610 \mathrm{~mm}, 60 \leq \mathrm{W}_{\mathrm{t}} \leq 4000 \mathrm{~g}\right)$. The allometry coefficient (b) of this relation was compared to value 3 with $\alpha=0.001$ with the help of the Student's $\mathrm{t}$ test. As we knew parameters of the Von Bertalanffy model and the allometry coefficient of the lengthweight relationship, we could calculate the theoretical weight at every age. The growth performance index $\Phi^{\prime}=\ln \mathrm{K}+2 \ln \mathrm{L}_{\infty}$ (Munro and Pauly, 1983) was used for making comparisons with other studies.

The reproductive period for both sexes combined was determined from the temporal development of the gonadosomatic index: GSI = (weight of gonad / total weight of the body) x 100. The hepatosomatic rate was also calculated monthly: HSI = (weight of the liver / total weight of the body) x 100. Monthly values of GSI and HSI were compared using a oneway ANOVA test completed by a multiple sample comparison of means (Dagnélie, 1970). The size at first sexual maturity was estimated according to the evolution of the proportion of mature fish according to size class during the reproduction period. It was the size at which $50 \%$ of individuals were ripe with functional gonads. The frequency of the different sexual states (juveniles, males, females) was also expressed according to size class during the reproduction season in November and December. These states are defined macroscopically according to whether the gonad functions as a testicle or an ovary. Testicles with sperm or granular ovaries with vitellogenic oocytes indicate the sex and activity state of the fish. 


\section{RESULTS}

The linear regression of total length versus scale radius was $\mathrm{L}_{\mathrm{t}}=85.43 \mathrm{R}-15.64(\mathrm{r}=0.92)$. The ordinate to the origin of this equation $(15.64 \mathrm{~mm})$ corresponds to the theoretical size of fish at the time of formation of the first scales. Comparing successive monthly mean marginal increment values (Fig. 1), using mean comparison tests, showed a significant difference $(\mathrm{P} \leq 0.001)$ between the months of November and December. Thus, we consider the rings to be annual increments. The value of the marginal increment is at its maximum when the ring is forming (November) and its minimum just after this (December).

Seven age classes, from 1 to 7 years old, were found. Backcalculated age-length pairs (Table 1) did not show any differences from the observed mean size-at-age (Table 2). The largest fish, which could not be aged, measured $61 \mathrm{~cm}(3411 \mathrm{~g})$. The estimated parameters of Von Bertalanffy's model are: $\mathrm{L}_{\infty}=$ $55.33 \mathrm{~cm}, \mathrm{~K}=0.513$ year $^{-1}$, to $=-0.282$. The growth performance index $\Phi$ is equal to 7.359 . The weight-

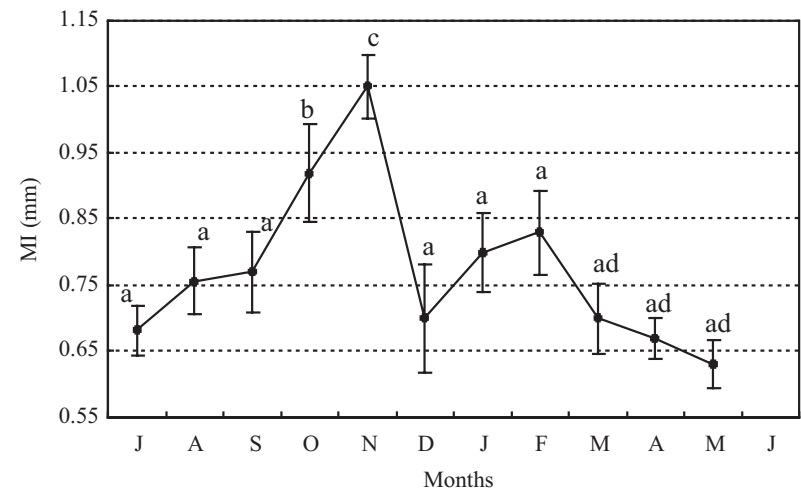

FIG. 1. - Monthly evolution of the marginal increment (MI $=R-R_{n}$ / $R_{n}-R_{n-1}$, where $R_{n}$ and $R_{n-1}$ are the radius of the last and the next-tolast growth rings respectively) of scales of gilthead seabream in Mellah lagoon, Algeria. The different letters indicate significant differences between sampling points.

length relationship $\mathrm{W}=1.29210^{-2} \mathrm{~L}^{3.06}(\mathrm{r}=0.96)$ shows isometric growth.

The GSI increased from October to reach its maximum by December, falling sharply to a minimum in January (Fig. 2). The HSI had a first peak $(2.59 \%)$ one month before that of the GSI and a second peak $(2.69 \%)$ in February. A one-way ANOVA

TABLE 1. - Total length $(\mathrm{cm})$ at the appearance of each growth ring in the scales of gilthead seabream from Mellah lagoon, Algeria. Ages I to VII represent the age obtained from direct scale readings. TL1 to TL7 are the backcalculated sizes-at-age.

\begin{tabular}{|c|c|c|c|c|c|c|c|}
\hline Age & TL1 & TL2 & TL3 & TL4 & TL5 & TL6 & TL7 \\
\hline I & $\begin{array}{c}\mathrm{N}=23 \\
\mathrm{M}=25.48 \\
\mathrm{Sd}=2.78\end{array}$ & & & & & & \\
\hline II & $\begin{array}{c}\mathrm{N}=17 \\
\mathrm{M}=27.21 \\
\mathrm{Sd}=2.25\end{array}$ & $\begin{array}{c}\mathrm{N}=17 \\
\mathrm{M}=38.82 \\
\mathrm{Sd}=2.68\end{array}$ & & & & & \\
\hline III & $\begin{array}{c}\mathrm{N}=5 \\
\mathrm{M}=27.72 \\
\mathrm{Sd}=2.00\end{array}$ & $\begin{array}{c}\mathrm{N}=5 \\
\mathrm{M}=40.72 \\
\mathrm{Sd}=3.43\end{array}$ & $\begin{array}{c}\mathrm{N}=5 \\
\mathrm{M}=48.26 \\
\mathrm{Sd}=2.92\end{array}$ & & & & \\
\hline IV & $\begin{array}{c}\mathrm{N}=4 \\
\mathrm{M}=27.44 \\
\mathrm{Sd}=1.09\end{array}$ & $\begin{array}{c}\mathrm{N}=4 \\
\mathrm{M}=38.79 \\
\mathrm{Sd}=2.47\end{array}$ & $\begin{array}{c}\mathrm{N}=4 \\
\mathrm{M}=45.35 \\
\mathrm{Sd}=2.27\end{array}$ & $\begin{array}{c}\mathrm{N}=4 \\
\mathrm{M}=49.06 \\
\mathrm{Sd}=1.07\end{array}$ & & & \\
\hline V & $\begin{array}{c}\mathrm{N}=3 \\
\mathrm{M}=30.08 \\
\mathrm{Sd}=0.85\end{array}$ & $\begin{array}{c}\mathrm{N}=3 \\
\mathrm{M}=41.32 \\
\mathrm{Sd}=0.53\end{array}$ & $\begin{array}{c}\mathrm{N}=3 \\
\mathrm{M}=44.34 \\
\mathrm{Sd}=0.86\end{array}$ & $\begin{array}{c}\mathrm{N}=3 \\
\mathrm{M}=47.73 \\
\mathrm{Sd}=1.25\end{array}$ & $\begin{array}{c}N=3 \\
M=50.10 \\
S d=1.66\end{array}$ & & \\
\hline VI & $\begin{array}{c}\mathrm{N}=11 \\
\mathrm{M}=25.32 \\
\mathrm{Sd}=4.23\end{array}$ & $\begin{array}{c}\mathrm{N}=11 \\
\mathrm{M}=37.54 \\
\mathrm{Sd}=2.14\end{array}$ & $\begin{array}{c}N=11 \\
M=44.64 \\
S d=2.56\end{array}$ & $\begin{array}{c}\mathrm{N}=11 \\
\mathrm{M}=48.48 \\
\mathrm{Sd}=1.45\end{array}$ & $\begin{array}{c}\mathrm{N}=11 \\
\mathrm{M}=51.83 \\
\mathrm{Sd}=2.15\end{array}$ & $\begin{array}{c}\mathrm{N}=11 \\
\mathrm{M}=53.35 \\
\mathrm{Sd}=1.52\end{array}$ & \\
\hline Vii & $\begin{array}{c}\mathrm{N}=5 \\
\mathrm{M}=26.65 \\
\mathrm{Sd}=1.86\end{array}$ & $\begin{array}{c}\mathrm{N}=5 \\
\mathrm{M}=37.38 \\
\mathrm{Sd}=1.75\end{array}$ & $\begin{array}{c}\mathrm{N}=5 \\
\mathrm{M}=44.73 \\
\mathrm{Sd}=1.68\end{array}$ & $\begin{array}{c}\mathrm{N}=5 \\
\mathrm{M}=47.78 \\
\mathrm{Sd}=0.97\end{array}$ & $\begin{array}{c}\mathrm{N}=5 \\
\mathrm{M}=51.67 \\
\mathrm{Sd}=1.64\end{array}$ & $\begin{array}{c}\mathrm{N}=5 \\
\mathrm{M}=52.56 \\
\mathrm{Sd}=1.72\end{array}$ & $\begin{array}{c}\mathrm{N}=5 \\
\mathrm{M}=54.41 \\
\mathrm{Sd}=1.84\end{array}$ \\
\hline Total & $\begin{array}{c}\mathrm{N}=68 \\
\mathrm{M}=26.46 \\
\mathrm{Sd}=2.50\end{array}$ & $\begin{array}{c}\mathrm{N}=45 \\
\mathrm{M}=38.74 \\
\mathrm{Sd}=2.63\end{array}$ & $\begin{array}{c}\mathrm{N}=28 \\
\mathrm{M}=45.27 \\
\mathrm{Sd}=2.51\end{array}$ & $\begin{array}{c}\mathrm{N}=23 \\
\mathrm{M}=48.35 \\
\mathrm{Sd}=1.29\end{array}$ & $\begin{array}{c}\mathrm{N}=19 \\
\mathrm{M}=51.58 \\
\mathrm{Sd}=1.94\end{array}$ & $\begin{array}{c}\mathrm{N}=16 \\
\mathrm{M}=53.14 \\
\mathrm{Sd}=1.53\end{array}$ & $\begin{array}{c}\mathrm{N}=5 \\
\mathrm{M}=54.41 \\
\mathrm{Sd}=1.84\end{array}$ \\
\hline
\end{tabular}

$\mathrm{N}$ : number, M: mean, Sd: standard deviation, TL: total length 
548

L. CHAOUI et al.

TABLE 2. - Age-length key for the gilthead seabream in Mellah lagoon, Algeria, sampled between July 1997 and June 1998.

\begin{tabular}{|c|c|c|c|c|c|c|c|c|}
\hline $\begin{array}{l}\text { Length interval } \\
(\mathrm{cm})\end{array}$ & 1 & 2 & 3 & Age (years) & 5 & 6 & 7 & $\begin{array}{l}\text { Number of } \\
\text { fish sampled }\end{array}$ \\
\hline $\begin{array}{l}19-20 \\
20-21 \\
21-22 \\
22-23 \\
23-24 \\
24-25 \\
25-26 \\
26-27 \\
27-28 \\
28-29 \\
29-30 \\
30-31 \\
31-32 \\
32-33 \\
33-34 \\
34-35 \\
35-36 \\
36-37 \\
37-38 \\
38-39 \\
39-40 \\
40-41 \\
41-42 \\
42-43 \\
43-44 \\
44-45 \\
45-46 \\
46-47 \\
47-48 \\
48-49 \\
49-50 \\
50-51 \\
51-52 \\
52-53 \\
53-54 \\
54-55 \\
55-56 \\
56-57 \\
57-58\end{array}$ & $\begin{array}{c}2 \\
4 \\
6 \\
7 \\
19 \\
44 \\
44 \\
53 \\
23 \\
4 \\
1\end{array}$ & $\begin{array}{c}1 \\
2 \\
1 \\
2 \\
8 \\
15 \\
8 \\
16 \\
5 \\
1\end{array}$ & $\begin{array}{l}1 \\
1 \\
1 \\
1 \\
3 \\
3 \\
1 \\
1\end{array}$ & $\begin{array}{l}1 \\
2 \\
1 \\
2\end{array}$ & $\begin{array}{l}2 \\
1 \\
1 \\
1\end{array}$ & (⿸丆口 & . & $\begin{array}{c}2 \\
4 \\
6 \\
7 \\
19 \\
44 \\
44 \\
53 \\
23 \\
4 \\
1 \\
1 \\
2 \\
1 \\
2 \\
8 \\
15 \\
8 \\
16 \\
6 \\
2 \\
1 \\
1 \\
3 \\
3 \\
1 \\
1 \\
1 \\
2 \\
1 \\
2 \\
5 \\
8 \\
6 \\
5 \\
6 \\
3 \\
3\end{array}$ \\
\hline $\begin{array}{l}\text { Total samples } \\
\% \text { of number } \\
\text { Mean length } \\
\text { Stand. deviation }\end{array}$ & $\begin{array}{c}207 \\
64.8 \\
25.09 \\
1.75\end{array}$ & $\begin{array}{c}58 \\
18.18 \\
36.93 \\
1.84\end{array}$ & $\begin{array}{c}12 \\
3.76 \\
44.19 \\
2.66\end{array}$ & $\begin{array}{c}6 \\
1.88 \\
50.10 \\
1.05\end{array}$ & $\begin{array}{c}5 \\
1.56 \\
52.40 \\
1.55\end{array}$ & $\begin{array}{c}25 \\
7.83 \\
53.87 \\
1.91\end{array}$ & $\begin{array}{c}6 \\
1.88 \\
54.91 \\
1.51\end{array}$ & 319 \\
\hline
\end{tabular}
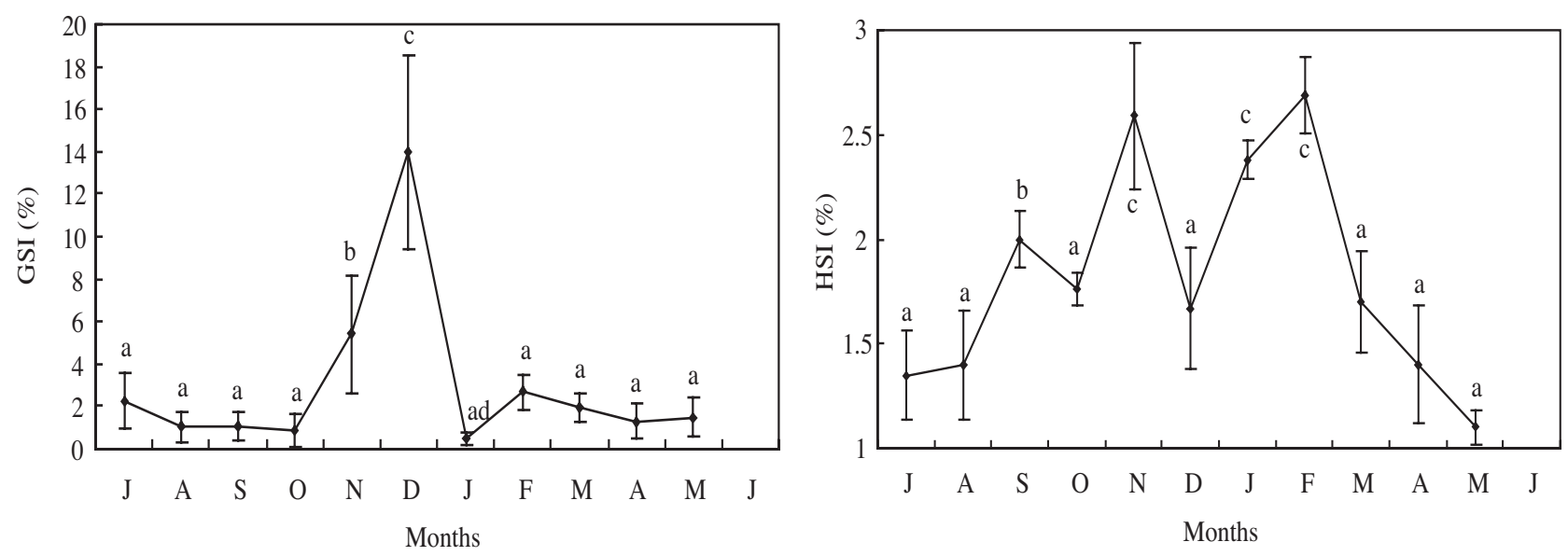

FIG. 2. - Monthly variation of the gonadosomatic index (GSI) and hepatosomatic index (HSI) of gilthead seabream in Mellah lagoon. No separation according to sex was made. The different letters indicate significant differences between sampling points. 


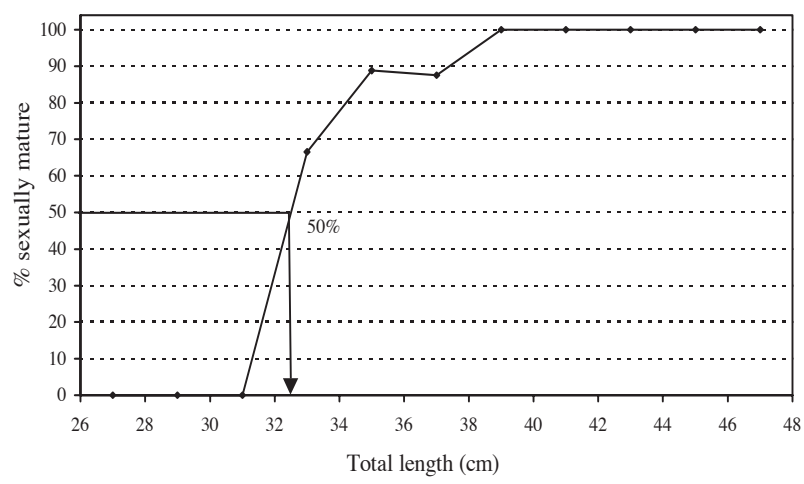

FIG. 3. - Sexual maturity curve of gilthead seabream as a function of total length in Mellah lagoon. The arrow indicates the total length at which $50 \%$ of fish were sexually mature. 99 fish were sampled in the months of November and December.

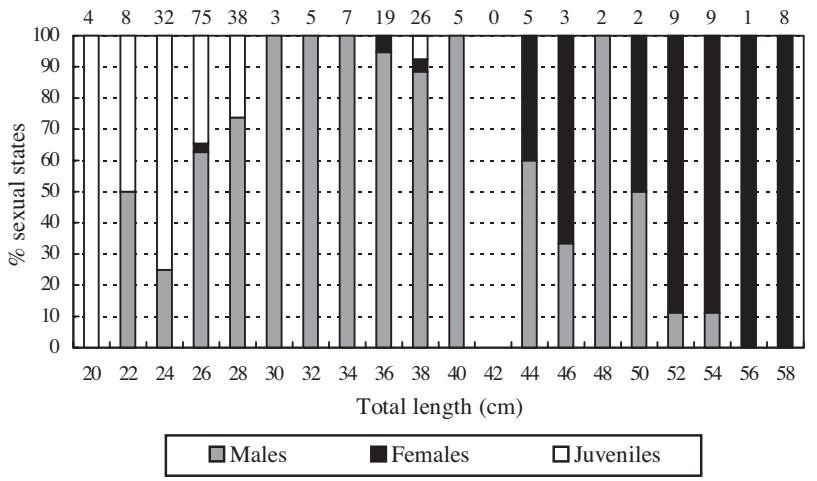

FIG. 4. - Frequency of different sexual states of gilthead seabream in Mellah lagoon as a function of total length. 265 Samples were collected in the months of November and December (see values above).

applied to mean values of GSI indicated their significant heterogeneity $(\mathrm{P}<0.01)$. Multiple sample comparisons of means showed that November and December are different from the other months and different between them. In the case of HSI, the difference is also significant $(\mathrm{P}<0.01)$. However, November, January and February are not different from each other, but they are different from the other months in the year. Gonad weight was very small in individuals of less than $30 \mathrm{~cm}$. Increasing values, reaching $240 \mathrm{~g}$ for $50 \mathrm{~cm}$ total length, were obtained from a length of $32 \mathrm{~cm}$. This size corresponds to the length of the smallest ripe individual whose gonad is functional. The size at which $50 \%$ of the population reaches maturity is $32.6 \mathrm{~cm}$ (Fig. 3).

For a total length less than $20 \mathrm{~cm}, 100 \%$ of the fish were juveniles, which dominate the size classes up to $24 \mathrm{~cm}$ (Fig. 4). Males, with a clear dominance of the testes part of the gonad, appeared from $22 \mathrm{~cm}$ and dominated until $48 \mathrm{~cm}$. Females were increasingly numerous in the larger size classes, and all fish greater than $56 \mathrm{~cm}$ were female.

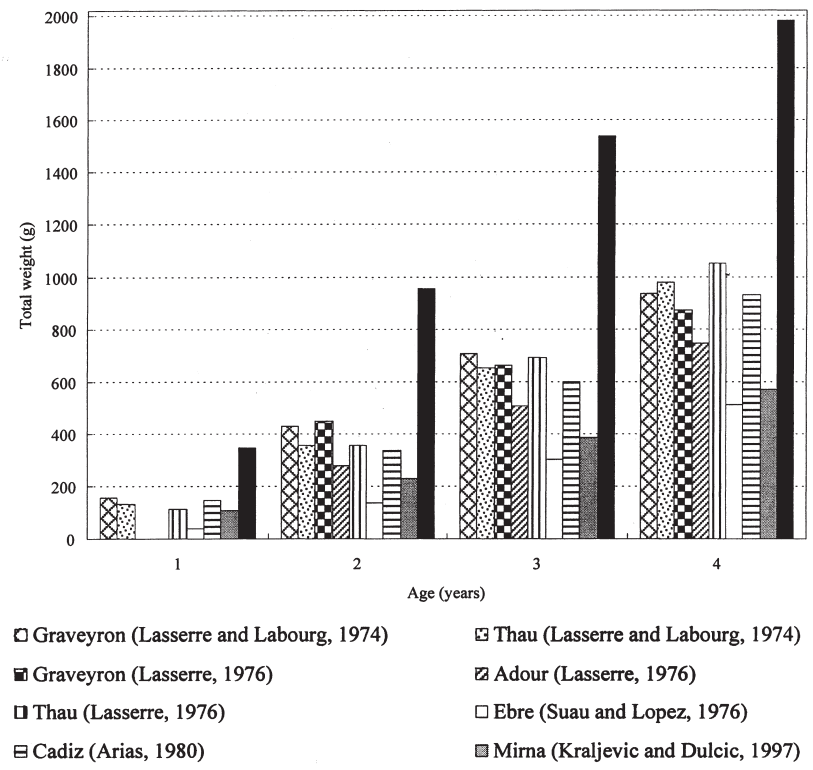

- Mellah lagoon (Present study)

FIG. 5. - Body weight of gilthead seabream as a function of age in different sectors of the Mediterranean Sea and Atlantic Ocean.

\section{DISCUSSION}

Scale marginal increment values suggest that only one growth ring is formed in November. This corresponds to the intense gametogenetic activity which starts in October and is completed in December. These months also constitute the period in which the temperatures are lowest, with $14.5^{\circ} \mathrm{C}$ in November, $12.5^{\circ} \mathrm{C}$ in December and an annual minimum of $11^{\circ} \mathrm{C}$ in January. When the water temperature is less than $11.8^{\circ} \mathrm{C}$ the seabream ceases growing (Kraljević, 1995). However, the energy invested into growing gonads seems to be the main factor responsible for the observed decrease in the somatic growth of gilthead seabream in Mellah lagoon. Temperature appears to affect feeding activity, which ceases completely in January.

About $65 \%$ of gilthead seabream belonged to the age group $1^{+}$year old, $18 \%$ to age group 2 years old and $4 \%$ to 3 years old. Juvenile individuals of this species are more common in lagoons, as reported by Lasserre (1976) in the Arcachon basin (France) and by Kraljević and Dulčić (1997) in Mirna estuary in the Adriatic Sea. Therefore, this confirms the importance of lagoons as nurseries for seabream.

Compared to other Mediterranean Sea and Atlantic Ocean areas where gilthead seabream are found, Mellah gilthead seabream grow exceptionally fast (Fig. 5) with a growth performance index of 
TABLE 3. - Growth parameters $\left(\mathrm{L}_{\infty}, \mathrm{K}, \mathrm{t}_{0}\right)$ and parameters of the weight-length relationship $(\mathrm{a}, \mathrm{b})$ of gilthead seabream in different localities (adapted from Kraljević et Dulčić (1997)).

\begin{tabular}{|c|c|c|c|c|c|c|c|c|c|}
\hline Locality & Age & $\mathrm{N}$ & $\mathrm{a}$ & $\mathrm{b}$ & $\mathrm{L}_{\infty}$ & $\mathrm{K}$ & $\mathrm{t}_{0}$ & $\Phi^{\prime}$ & Author \\
\hline Mellah lagoon & $1-7$ & 370 & 0.0129 & 3.067 & 55.33 & 0.513 & -0.282 & 7.359 & Present study \\
\hline Graveyron (France) & $1-4$ & 126 & 0.0144 & 3.075 & 42.29 & 0.456 & -0.451 & 6.704 & Lasserre and Labourg (1974) \\
\hline Thau (France) & $1-4$ & 713 & 0.0226 & 2.886 & 62.02 & 0.221 & -0.774 & 6.745 & Lasserre and Labourg (1974) \\
\hline Segura (Spain) & $2-6$ & 135 & 0.0289 & 2.907 & 53.00 & 0.315 & - & 6.785 & Arnal et al. (1976) \\
\hline Graveyron (France) & $2-5$ & 94 & 0.0541 & 2.618 & 53.48 & 0.264 & -1.340 & 6.627 & Lasserre (1976) \\
\hline Adour (France) & $2-5$ & 79 & 0.0575 & 2.590 & 56.17 & 0.265 & -0.409 & 6.729 & Lasserre (1976) \\
\hline Thau (France) & $1-4$ & 383 & 0.0121 & 3.064 & 57.66 & 0.272 & -0.541 & 6.807 & Lasserre (1976) \\
\hline Ebre (Spain) & $1-7$ & 611 & $11210^{-7 *}$ & 3.055 & 62.19 & 0.171 & -0.531 & 6.494 & Suau and López (1976) \\
\hline Cádiz (Spain) & $1-7$ & 1775 & $7110^{-7 *}$ & 3.120 & 84.55 & 0.130 & -1.586 & 6.834 & Arias (1980) \\
\hline South West Portugal & & 231 & $182710^{-8}$ & 2.960 & - & - & - & - & Gonçalves et al. (1997) \\
\hline Mirna (Croatia) & $1-12$ & 314 & 0.0112 & 3.052 & 59.76 & 0.153 & -1.711 & 6.303 & Kraljević and Dulčić (1997) \\
\hline
\end{tabular}

* Measurements taken in $\mathrm{mm}$ and $\mathrm{g}$ (from other authors' measurements taken in $\mathrm{cm}$ and $\mathrm{g}$ ).

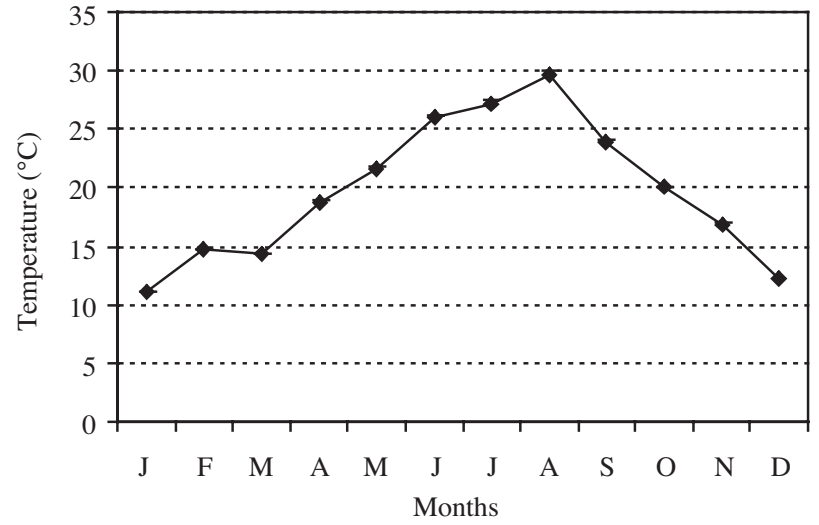

FIG. 6. - Monthly temperature variation in Mellah lagoon during 1998 (Draredja and Kara, 2004).

$\Phi^{\prime}=7.359$ (Table 3). It is known that lagoonal environments are highly productive (Sacchi, 1973; Kapetsky, 1984; Labourg et al., 1985), which results in higher growth compared to coastal marine environments (Amanieu, 1973; Chauvet, 1979). In the case of Mellah lagoon, some very favourable thermal conditions partly explain this performance: Temperatures recorded in this area were higher than $15^{\circ} \mathrm{C}$ during eight months of the year $\left(15-30^{\circ} \mathrm{C}\right)$ and did not go lower than $11^{\circ} \mathrm{C}$ (Fig. 6). They were lower than this value (between 5.5 and $11^{\circ} \mathrm{C}$ ) for at least four months of the year, for example within Thau's pond (France) (Blanchet-Besseon, 1986), where the growth performance was clearly lower (Lasserre and Labourg, 1974; Lasserre, 1976) than that recorded in Mellah lagoon.

The allometry coefficient of the length-weight relationship $(b=3.067)$ indicates isometric growth. This value is equal to the one recorded in the Arcachon basin, France (Lasserre and Labourg, 1974), in Thau's pond, France (Lasserre, 1976) and in the Ebre, Spain (Suau and Lopez, 1976) and Mirna (Croatia) estuaries (Kraljevic and Dulčić, 1997).
According to the variation in GSI, maturation and reproduction takes place in Mellah lagoon between October and January, with gonad maturation between October and December and spawning during December. Reproduction takes place in the same period in the northern Mediterranean Sea (Lasserre, 1976) and in the Atlantic Ocean (Arias, 1980). HSI increased from August in response to the intensification of dietary activity resulting in an active hepatic metabolism. The first maximal HSI value precedes that of GSI, which indicates an energetic transfer to the gonads. Indeed, fishes which decrease their food intake during gonadal maturation use nutrients originating from endogenous reserves in muscle, adipose tissue and liver (Lal and Singh, 1987; Nassour and Leger, 1989; Matin et al., 1993). During breeding, despite the fact that gilthead seabream females continue feeding during the spawning season, they probably use their liver reserve during the gonadal maturation process (Almansa et al., 2001). The success of reproduction of gilthead seabream in Mellah lagoon could be the result of salinity conditions that are favourable for the osmotic requirements of gametogenesis. Indeed, the increase in salinity of this medium is perceptible with a value of about $35 \%$ during gonad maturation (October to December) and a yearly mean value of 29.6\%o (Draredja and Kara, 2004).

First sexual maturity was reached at $32.6 \mathrm{~cm}$, at an average age of 18 months. Arias (1980) indicated that between size classes 30 to $32 \mathrm{~cm}$ and 34 to 36 $\mathrm{cm}, 82.2 \%$ of males were spermiating. Bi-modal distribution of size frequencies according to the different sexual states (males, females, juveniles), with males occupying the smallest sizes and a sex-ratio in their favour, confirm the protandric hermaphroditism (Sadovy and Shapiro, 1987; Yeung and Chan, 
1987), with a sexual inversion that takes place essentially from size class 43 to $45 \mathrm{~cm}$. Zohar et al. (1984) came to the same conclusion about first maturity of gilthead seabream in cultivation. He found first maturity to take place at 1 year, but detected 30 to $40 \%$ of sex inversions at the end of the second year (Zohar et al., 1978). The sex change of $S$. aurata generally takes place 1 year after the first male activity (D'Ancona, 1941; Lasserre, 1976), but D'Ancona (1941) and Bruslé-Sicard and Fourcault (1997) emphasised the possibility of a later sex inversion. Our results support this hypothesis since only $40 \%$ of the field specimens studied changed sex at $2^{+}$years. Bruslé-Sicard and Fourcault (1997) suggested histocytological criteria that allow the functional sex during the subsequent maturation to be determined. However, sex change may not only be related to individual determinism but could depend on the environmental and social conditions (Happe and Zohar, 1988). This successive hermaphroditism type is different from the one observed in the Diplodus species from South African coasts (Mann and Buxton, 1998). The latter are characterised by rudimentary hermaphroditism, with males and females developing before sexual maturation from an immature bisexual gonad.

\section{ACKNOWLEDGEMENTS}

This research was supported by the AlgerianFrench cooperation program (CMEP, $\mathrm{N}^{\circ} 04 \mathrm{MDU}$ 628), entitled "Ichtyofaune côtière du golfe d'Annaba: diversité génétique et biologie halieutique".

\section{REFERENCES}

Almansa, E., M.V. Martin, J.R. Cejas, P. Badia, S. Jerez and A. Lorenzo. - 2001. Lipid and fatty acid composition of female gilthead seabream during their reproductive cycle: effects of a diet lacking n-3 HUFA. J. Fish Biol., 59: 267-286.

Amanieu, M. - 1973. Ecologie et exploitation des étangs et lagunes saumâtres du littoral français. Ann. Soc. Roy. Zool. Belg., 103(1): 79-94.

Anonymous. - 2004. Study of the market for aquaculture produced seabass and seabream species. Final Report to the European Commission, DG Fisheries. University of Stirling, Department of Marketing. 84 p.

Arias, A. - 1980. Crecimento, régimen, alimentarión y reproducción de la dorada (Sparus aurata L.) y del róbalo (Dicentrarchus labrax L.) en los esteros de Cádiz. Inv. Pesq. 44: 59-83.

Arnal, J., A.G. Alcazar and A. Ortega. - 1976. Observaciones sobre el crecimento de la dorada (Sparus aurata L.) en el Mar Menor (Murcia). Bol. Inst. Esp. Oceanogr., 221-222: 1-17.

Bânârescu, P. - 1964. Fauna republicii populare romine (Pisces-
Osteichthyes). Edit. Acad. Republ. Pop. Romine, Bucuresti, 960 pp.

Bauchot, M.L. and J.C. Hureau. - 1986. Sparidae. In: P.J. Whitehead, M.L. Bauchot, J.C. Hurau, J. Nielsen and E. Tortonese (eds.), Fishes of the North-eastern Atlantic and Mediterranean, vol. 2, pp. 883-907. UNESCO, Paris.

Blanchet-Besson, C. - 1986. Les paramètres physico-chimiques en élevage larvaire intensif et la toxicité aiguë de l'ammoniaque et des nitrites vis à vis du loup Dicentrarchus labrax (L. 1758). Ph. D. thesis, Univ. Montpellier II.

Bruslé-Sicard, S. and B. Fourcault. - 1997. Recognition of sexinverting protandric Sparus aurata: ultrastructural aspects. $J$. Fish. Biol., 50: 1094-1103.

Chatain, B. - 1997. Development and achievements of marine fishrearing technology in France over the last 15 years. Hydrobiol., 358: 7-11

Chauvet, C. - 1979. Préliminaire à l'étude de la biologie et de la dynamique du stock tunisien de Sparus aurata (L. 1758). Synopsis de la croissance groupes 0, 1, 2. Bull. Off. Nat. Pêches, 3(2): 241-253.

D'Ancona, U. - 1941. Ulteriori osservazioni sull'ermafroditismo e il differenziamento sessuale dell'orata (Sparus aurata L.) (Completamento delle ricerche della Dott. A. Pasquali). Pubbl. Staz. Zool. Napoli, 18: 313-336.

Dagnélie, P. - 1970. Théorie et méthodes statistiques, Vol. 2: les méthodes de l'inférence statistique. Duculot ed., Gembloux.

Draredja, B. and M. H. Kara. - 2004. Caractères physico-chimiques de la lagune Mellah (Algérie Nord-Est). Rapp. Comm. Int. Mer Médit., 37. 93.

Ferrari, I. and A.R. Chieregato. - 1981. Feeding habits of juvenile stages of Sparus auratus L., Dicentrarchus labrax L. and Mugilidae in a brackish embayment of the Po River delta. Aquaculture, 25: 243-257.

Happe, A. and Y. Zohar. - 1988. Self fertilization in the protandrous hermaphrodite Sparus aurata: development of the technology. In: Y. Zohar and B. Breton (eds.), Reproduction in fish. Basic and applied aspects in endocrinology and genetics, pp. 177-180. Les colloques de l'INRA, n 44, Paris: INRA.

Kapetsky, J.M. - 1984. Coastal lagoon fisheries around the world: some perspectives on fishery yields, and other comparative fishery characteristics. In: J.M. Kapetsky and G. Lasserre (eds), Management of coastal lagoon fisheries. Studies and reviews, CGPM 61(2): 97-140.

Kraljević, M. - 1995. Rast komarce, Sparus aurata, i pica, Diplodus puntazzo Cetti, u prirodnim i kontroliranim uvjetima. Ph. D. thesis, Univ. Zagreb.

Kraljević, M. and J. Dulčić. - 1997. Age and growth of gilt-head seabream (Sparus aurata L.) in the Mirna Estuary, Northern Adriatic. Fish. Res., 31: 249-255.

Labourg, P.J., C. Clus and G. Lasserre. - 1985. Résultats préliminaires sur la distribution des juvéniles de poissons dans un marais maritime du bassin d'Arcachon. Oceanol. Acta 8(3): 331-341.

Lal, B. and T.P. Singh. - 1987. Changes in tissue lipid levels in the freshwaters catfish (C. batrachus) associated with the reproductive cycle. Fish Physiol. Biochem., 3: 191-201.

Lasserre, G. - 1976. Dynamique des populations ichthyologiques lagunaires. Application à Sparus aurata. Ph. D. thesis, Univ. Montpellier II.

Lasserre, G. and P.J. Labourg. - 1974. Etude comparée de la croissance de la daurade Sparus aurata L. des régions d'Arcachon et de Sète. Vie Milieu, 24(1A): 155-170.

Lee, R.M. - 1920. A review of the methods of age and growth determination in fishes by means of scale. Fish. Invest., 2(4): 1-32.

Mann, B.Q. and C.D. Buxton. - 1998. The reproductive biology of Diplodus sargus capensis and D. cervinus hottentotus (Sparidae) off the south-east Cape coast, South Africa. Cybium, 22(1): 31-47.

Martin, N.B., D.F. Houlihan, C. Talbot and R.M. Palmer. - 1993. Protein metabolism during sexual maturation in female Atlantic salmon (S. salar L). Fish Physiol. Biochem., 12: 131-141.

Munro, J.L. and D. Pauly. - 1983. A simple method for comparing growth of fishes and invertebrates. ICLARM Fishbyte, 1: 5-6.

Nassour, I. and C.L. Leger. - 1989. Deposition and mobilization of body fat during sexual maturation in female trout (Salmo gairdneri R.). Aquat. Liv. Resour., 2: 153-159.

Pita, C., S. Gamito and K. Erzini. - 2002. Feeding habits of the gilt- 
head seabream (Sparus aurata) from the Ria Formosa (southern Portugal) as compared to the black seabream (Spondyliosoma cantharus) and the annular seabream (Diplodus annularis). $J$. Appl. Ichthyol., 18: 81-86.

Prager, M.H., S.B. Saila and C.W. Recksiek. - 1989. Fishparm: a microcomputer program for parameter estimation of nonlinear models in fishery science, second edition. Old Dominion Univ. Oceanogr. Tech. Rep. 87-10.

Rosecchi, E. - 1987. L'alimentation de Diplodus annularis, Diplodus sargus, Diplodus vulgaris et Sparus aurata (Pisces, Sparidae) dans le Golfe du Lion et les lagunes littorals. Rev. Trav. Inst. Pêches Marit., 49: 125-141.

Sacchi, C.F. - 1973. Les milieux saumâtres méditerranéens: dangers et problèmes de productivité et d'aménagement. Arch. Oceanogr. Limnol., 18: 23-58.

Sadovy, Y. and D.Y. Shapiro. - 1987. Criteria for the diagnosis of hermaphroditism in fishes. Copeia, 1: 136-156.

Shields, R.J. - 2001. Larviculture of marine finfish in Europe. Aquaculture, 200: 55-88.

Suau, P. and J. López. - 1976. Contribución al estudio de la dorada, Sparus aurata L. Inv. Pesq., 40: 169-199.
Von Bertalanffy, L. - 1938. A quantitative theory of organic growth. Human Biol., 10(2): 181-213.

Wassef, E.A. and A. Eisawy. - 1985. Food and feeding habits of wild and reared gilthead bream Sparus aurata L. Cybium, 9: 233-242.

Yeung, W.S.B. and S.T.H. Chan. - 1987. The gonadal anatomy and sexual pattern of the protandrous sex-reversing fish, Rhabdosargus sarba. J. Zool., London, 212: 521-532.

Zohar, Y., M. Abraham and H. Gordin. - 1978. The gonadal cycle of the captivity-reared hermaphroditic teleost Sparus aurata (L.) during the first two years of life. Ann. Biol. Anim. Biochim. Biophys., 18: 877-882.

Zohar, Y., R. Billard and C. Weil. - 1984. La reproduction de la daurade (Sparus aurata) et du bar (Dicentrarchus labrax): connaissance du cycle sexuel et contrôle de la gamétogenèse et de la ponte. In: G. Barnabé and R. Billard (eds.), L'aquaculture du bar et des sparidés, pp. 3-24. INRA Publ., Paris.

Scient. ed.: S. Zanuy

Received July 16, 2004. Accepted February 23, 2006.

Published online August 22, 2006. 